\title{
Symptom management theory applied to nursing care: scoping review
}

\author{
Teoria de manejo de sintomas aplicada ao cuidado de enfermagem: scoping review \\ Teoría de manejo de síntomas aplicada al cuidado de enfermería: scoping rewiew
}

Lara Adrianne Garcia Paiano da Silva' ORCID: 0000-0003-4419-6984

Vagner José Lopes' ORCID: 0000-0002-6635-4325

Nen Nalú Alves das Mercês' ORCID: 0000-0001-5843-8329

'Universidade Federal do Paraná. Curitiba, Paraná, Brazil.

How to cite this article: Silva LAGP, Lopes VJ, Mercês NNA. Symptom management theory applied to nursing care: scoping review. Rev Bras Enferm. 2021;74(3):e20201004. https://doi.org/10.1590/0034-7167-2020-1004

\section{Corresponding author:}

Lara Adrianne Garcia Paiano da Silva

E-mail: laraagps@gmail.com

EDITOR IN CHIEF: Antonio José de Almeida Filho ASSOCIATE EDITOR: Hugo Fernandes

Submission: 09-27-2020 Approval: 12-11-2020

\begin{abstract}
Objectives: to identify publications about the applicability of the Symptom Management Theory in nursing care to pediatric, adolescent, adult and elderly patients. Methods: scoping review following the steps: definition of the objective, research question and inclusion criteria; search, selection and analysis of publications; synthesis of results. The search occurred in the VHL, SciELO, CAPES and PubMed Journals Portal bases, contemplating publications between 1994 and July 2020. Results: out of 3,286 studies, ten were selected, published between 2008 and 2019. They described the relationships between the participants and the domains (person, environment, health and disease), components (symptom experience, management strategies, results) and presented strategies for symptom management. Conclusions: the Symptom Management Theory was considered applicable to the participants of the studies and to nursing care. It was concluded that understanding the interaction of these elements is essential to plan actions aimed at controlling symptoms effectively.

Descriptors: Nursing Care; Signs and Symptoms; Assessment of Symptoms; Nursing Theory; Review.
\end{abstract}

\section{RESUMO}

Objetivos: identificar publicações acerca da aplicabilidade da Teoria de Manejo de Sintomas no cuidado de enfermagem a pacientes pediátricos, adolescentes, adultos e idosos. Métodos: scoping review seguindo as etapas: definição do objetivo, pergunta de pesquisa e critérios de inclusão; busca, seleção e análise das publicações; síntese dos resultados. A busca ocorreu nas bases BVS, SciELO, Portal de Periódicos CAPES e PubMed, contemplando publicações entre 1994 e julho de 2020. Resultados: de 3.286 estudos, 10 foram selecionados, publicados entre 2008 e 2019. Descreveram as relações entre os participantes e os domínios (pessoa, ambiente, saúde e doença), componentes (experiência de sintomas, estratégias de manejo, resultados) e apresentaram estratégias para o manejo dos sintomas. Conclusões: a Teoria de Manejo de Sintomas foi considerada aplicável aos participantes dos estudos e ao cuidado de enfermagem. Concluiu-se que compreender a interação desses elementos é essencial para planejar ações voltadas ao controle dos sintomas de forma eficaz.

Descritores: Cuidado de Enfermagem; Sinais e Sintomas; Avaliação de Sintomas; Teoria de Enfermagem; Revisão.

\section{RESUMEN}

Objetivos: identificar publicaciones acerca de aplicabilidad de Teoría de Manejo de Síntomas en cuidado de enfermería a pacientes pediátricos, adolescentes, adultos y ancianos. Métodos: scoping review siguiendo las etapas: definición del objetivo, cuestión de investigación y criterios de inclusión; búsqueda, selección y análisis de publicaciones; síntesis de resultados. Búsqueda ocurrió en bases BVS, SCIELO, Portal de Periódicos CAPES y PubMed, contemplando publicaciones entre 1994 y julio de 2020. Resultados: de 3.286 estudios, 10 seleccionados, publicados entre 2008 y 2019. Describieron relaciones entre los participantes y los dominios (persona, ambiente, salud y, enfermedad), componentes (experiencia de síntomas, estrategias de manejo, resultados) y presentaron estrategias para el manejo de los síntomas. Conclusiones: Teoría de Manejo de Síntomas considerada aplicable a los participantes de los estudios y al cuidado de enfermería. Concluyó que comprender la interacción de esos elementos es esencial para planear acciones vueltas al control de los síntomas de forma eficaz.

Descriptores: Cuidado de Enfermería; Señales y Síntomas; Evaluación de Síntomas; Teoría de Enfermería; Revisión. 


\section{INTRODUCTION}

Nursing theories constitute a set of concepts with the proposal of specific results that vary according to their scope and propositions representing, in general, the description of the properties and dimensions of a concept ${ }^{(1)}$, i.e. an idea or mental construction that comprises abstract attributes of reality, inserted in a context, and that can be applicable (e.g. abstract concepts: care, grief and respect; concrete concepts: fever, pain, fatigue) (2). Thus, the theories provide systematic explanations of the relationships between phenomena including the descriptions of concepts and propositions, which are directly linked to research and experiences of nursing practice ${ }^{(2-3)}$; just as the conceptual model is the symbolic representation of the relations between the variables and concepts ${ }^{(3)}$.

The application of a theory in the nursing care process aims the scientific support for the clinical practice and nursing actions ${ }^{(2)}$, besides contributing to the development and expansion of Nursing knowledge and its evolution as a profession and science ${ }^{(1-2)}$.

In this context, in order to guide research on symptoms and clinical practice in nursing, researchers, nurses, members of the Symptom Management Teachers Group of the University of California at San Francisco School of Nursing published in 1994 a conceptual model to illustrate the multidimensional process of symptom management, the Symptom Management Model (SMM), which was developed under the premise that effective management of any symptom or group of symptoms should consider three components: symptom experience, symptom management strategies, and outcomes ${ }^{(3-4)}$.

This model was revised in 2001 and, in its updated version, incorporated the symptom management process in the context of the nursing science domains: the person, the environment and health and disease. In 2008, in a new update, the model was consolidated as a medium range theory named Symptom Management Theory (SMT) ${ }^{(4)}$.

Considering the definition of symptom as a subjective experience that reflects on an individual's biopsychosocial functions and sensations or cognition, and considering that the definition of signs is any abnormality indicative of disease, the SMT researchers were concerned about how important the signs and symptoms were and could provide indications about the individuals' conditions to evaluate them, as well as manage strategies to control symptoms ${ }^{(3)}$.

In this sense, SMT aims to guide clinical practice through subjective and systematic evaluation of symptoms, planning and selection of interventions and their evaluations and aims to guide research, proposing specific questions and assumptions for symptom management. Its theoretical assumptions are based on the relationships between its variables, which are: evaluation of symptoms based on the perception of the individual who experiences them and evaluates himself/herself; application to individuals who experience the symptom or have the risk of developing it; evaluation and interpretation of symptoms of individuals with difficulty to express themselves verbally, identified by their caregivers; control of all symptoms; strategies for management of symptoms extended to the family, group or work environment beyond the individual himself/herself; and management of symptoms as a dynamic process, which can be modified according to the results obtained by the individual and their relationships with variables and areas of theory (person, environment, health and disease) ${ }^{(3,5)}$.

Since its publication, throughout these years, the conceptual model that was later consolidated as a theory has been applied by nurses and has contributed to the progression of studies on the experience of symptoms, management strategies and results obtained in its manifestations ${ }^{(5)}$. However, they are presented, in theoretical and reflective studies. Thus, considering that the SMT has been a reference for the approach of symptom management, it is necessary to investigate how and in which contexts it is applied in clinical practice and nursing care.

\section{OBJECTIVES}

To identify publications about the applicability of the Symptom Management Theory in nursing care to pediatric, adolescent, adult and elderly patients.

\section{METHODS}

This is a review of the scope that followed the research question: How Symptom Management Theory has been applied to nursing care for pediatric, adolescent, adult and elderly patients?

The scope review is presented as a literature review model described by Arksey and O'Malley as a technique to map the literature in the area of interest of the researcher, with a tendency to address broader topics, identifying the relevant literature on the subject under study; it allows the application of different research designs and does not aim to assess the quality of the studies included ${ }^{(6)}$. This type of review is used to: identify the types of evidence available in a given field; identify and analyze knowledge gaps; clarify the main concepts and definitions in the literature; examine how research is conducted on a given topic or field; and identify the main characteristics or factors related to a concept $t^{(7)}$, which corroborates the research proposal in identifying the applicability of the Symptom Management Theory in nursing care.

The recommendations published in the JBI Manual for Evidence Synthesis, version 2020, were followed for its development, contemplating the following steps: defining objective and research question; defining inclusion criteria; defining strategy for data selection and extraction; searching, selection and analysis of publications in information sources; and presentation and synthesis of results ${ }^{(7)}$.

Once the objective of this study was established, the above research question was elaborated using the PCC mnemonic, in which " $\mathrm{P}$ " means population, " $\mathrm{C}$ "concept and " $\mathrm{C}$ "context. Thus, they are defined as $\mathrm{P}$ - pediatric, adolescent, adult and elderly patients; C - Symptom Management Theory; and C - nursing care.

As for the inclusion criteria for the selection of publications, the following were considered: having been published in Portuguese, English and Spanish between 1994 and July 2020; being available online for consultation; and meeting the objective of the study. The period selected for searching publications is justified by the fact that the symptom management model was developed in the early 1990s and published in 1994. Moreover, since its publication, no review studies addressing its applicability have been identified. Review studies and those that did not meet the previously established criteria were excluded. 
For the steps contemplating the search strategies, selection, extraction and analysis of publications, the recommendations of Preferred Reporting Items for Systematic reviews and Meta-Analyses extension for Scoping Reviews (PRISMA - ScR) were adopted ${ }^{(8)}$. The search occurred in journals in the Virtual Health Library (VHL), Scientific Electronic Library Online (SciELO) and Periodical Portal of the Coordination for the Improvement of Higher Level Personnel (CAPES) and in the PubMed information source of the U.S. National Institutes of Health's National Library of Medicine, using the Boolean operators AND or OR for the combination of the following terms of the Health Sciences Descriptors (DeCs) and Medical Subject Headings (MeSH): signs and symptoms, signs and symptoms, symptom assessment, nursing theory, nursing care, pediatric nursing, adult; and the key words: Symptom Management Theory, Symptom Management Model and Conceptual model of symptom management, according to the strategy presented in Chart 1.

Chart 1 - Search strategy for study selection

\begin{tabular}{|l|l|}
\hline Keywords / DeCs/MeSH Descriptors & $\begin{array}{l}\text { Virtual libraries / } \\
\text { Information sources }\end{array}$ \\
\hline $\begin{array}{l}\text { Symptom management theory OR Nursing theory } \\
\text { AND Symptom management model AND Signs } \\
\text { and symptoms OR Symptom evaluation AND } \\
\text { Nursing care AND Pediatric nursing AND Adult }\end{array}$ & $\begin{array}{l}\text { Virtual Health Library } \\
\text { Scientific Electronic } \\
\text { Library Online } \\
\text { CAPES Journal Portal }\end{array}$ \\
\hline $\begin{array}{l}\text { Symptoms management theory OR Nursing } \\
\text { theory AND Conceptual model of symptom } \\
\text { management AND Signs and symptoms OR } \\
\begin{array}{l}\text { Symptom assessment AND nursing care AND } \\
\text { Pediatric nursing AND Adult }\end{array}\end{array}$ & PubMed* \\
\hline
\end{tabular}

Notes: DeCs - Health Sciences Descriptors; MeSh - Medical Subject Headings; PubMed - U.S. National Institutes of Health's National Library of Medicine Information Source; CAPES Journal Portal - the Coordination for the Improvement of Higher Level Personnel Journal Portal.

The keywords Symptom Management Model and Conceptual Model of Symptom Management were selected for the search strategy due to the development of SMT which was first elaborated as a conceptual model. Thus, both in the selection phase of publications and in the analysis of results, studies addressing the Symptom Management Model and the Symptom Management Theory were considered.

After the search in the virtual libraries and source of information, the reading of the titles and abstracts was carried out, duplicate studies and those that did not correspond to the interests of this research were excluded. Then, those that met the inclusion criteria were selected for full reading and synthesized for analysis.

The strategy stage of search and selection of publications was developed by two independent reviewers. Each reviewer applied the search strategy and selected the studies that, in their judgment, met the inclusion criteria. Disagreements were identified regarding the selection of studies, which were discussed in a synchronous remote meeting with the third author. After checking the studies and analyzing the results, the reviewers reached a consensus and listed the studies that make up the final sample of this review, with no need to request additional information or data from the authors of the selected studies.

\section{RESULTS}

The studies located in the search totaled 3,286 publications, ten of which were selected to compose the final sample of this scope review. The process of identification, screening and selection of the studies is presented in Figure 1:

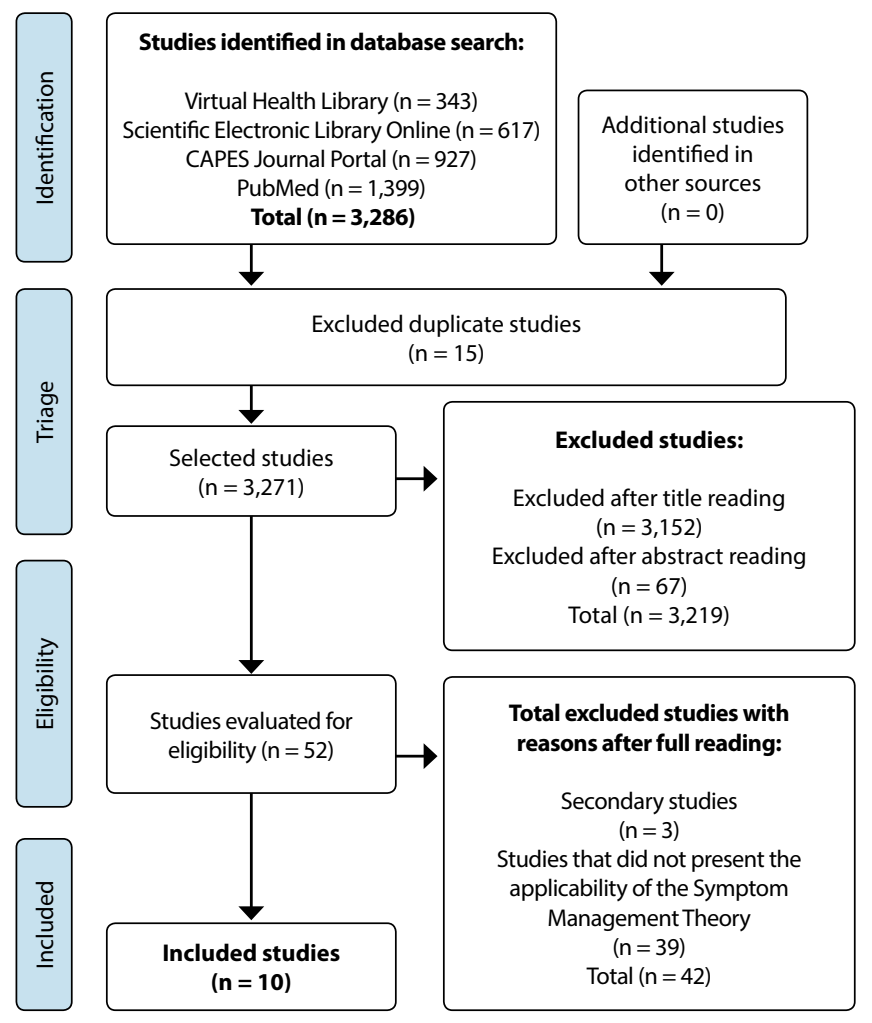

Figure 1 - Process of identification, screening and selection of studies

Of the ten studies selected, six were published in English, two in Portuguese and English and two in Spanish. As for the country, two were conducted in Brazil, two in the United States, two in Colombia, one in Turkey, one in the United Kingdom, one in South Korea and one in China. The studies were published between 2008 and 2019, being of the qualitative (3), descriptive (1), critical reflection (3), quantitative (1), methodological (1) and revision (1) types. This last study, classified by the journal that published it in 2014 as a review article, did not indicate in its method the stage of search and selection of articles, but was selected for the final sample of this review of scope, because its content described the applicability of SMT in the construction of another model of care and met the objective intended in this study.

Regarding the participants, the investigations were carried out with women with type II diabetes mellitus; children with cancer; adult patients with colorectal cancer; women with acute coronary syndrome; elderly with arthritis; adults in post-operative orthopedic, gynecological, neurological and digestive tract surgeries; adults with Behcet's disease; and adolescents with Human Immunodeficiency Virus (HIV).

The selected publications are presented in Chart 2.

Regarding the SMT and the Symptom Management Model approach by the selected studies, in some of them the authors described the domains (person, environment, health and disease), the components (symptom experience, symptom management strategies and results) and presented strategies for symptom management, as presented in Chart 3. 
Chart 2-Synthesis and characterization of the studies selected for the scope review

\begin{tabular}{|c|c|c|c|}
\hline $\begin{array}{l}\text { Title, country, year of } \\
\text { publication, journal and } \\
\text { virtual library/information } \\
\text { source }\end{array}$ & Objective & $\begin{array}{l}\text { Method (Type of study, } \\
\text { Participants) }\end{array}$ & Main results \\
\hline $\begin{array}{l}\text { Conceptual Model of Symptom- } \\
\text { Focused Diabetes Care for African } \\
\text { Americans }^{(9)} \\
\text { United States of America } \\
2008 \\
\text { Journal of Nursing Scholarship } \\
\text { PubMed* }\end{array}$ & $\begin{array}{l}\text { Describe a conceptual } \\
\text { model focused on } \\
\text { symptoms and strategies } \\
\text { to improve self-care } \\
\text { practices and quality of } \\
\text { life perceptions of African- } \\
\text { American women with } \\
\text { type Il diabetes. }\end{array}$ & $\begin{array}{l}\text { Type of study: descriptive } \\
\text { research } \\
\text { Population/sample: African- } \\
\text { American women with type II } \\
\text { diabetes. }\end{array}$ & $\begin{array}{l}\text { Conceptual model focused on symptoms with } \\
\text { innovative approach for the care of a distinct } \\
\text { population, involving the participants in the self-care, } \\
\text { relevant result in relation to the population studied, } \\
\text { since diabetes is one of the main causes of morbidity } \\
\text { and mortality in African-Americans and the self- } \\
\text { management of diabetes is the basis of care. }\end{array}$ \\
\hline $\begin{array}{l}\text { Analysis of the UCSF Symptom } \\
\text { Management Theory: } \\
\text { Implications for Pediatric } \\
\text { Oncology Nursing }{ }^{(4)} \\
\text { United States of America } \\
2010 \\
\text { Journal of Pediatric Oncology } \\
\text { Nursing } \\
\text { PubMed* }\end{array}$ & $\begin{array}{l}\text { Analyze the applicability } \\
\text { of the Symptom } \\
\text { Management Theory in } \\
\text { studies with children with } \\
\text { cancer. }\end{array}$ & $\begin{array}{l}\text { Type of study: critical reflection } \\
\text { Population/sample: children } \\
\text { with cancer }\end{array}$ & $\begin{array}{l}\text { The application of theory to studies involving children } \\
\text { has been limited to descriptive studies that test parts of } \\
\text { the theory. Its strengths include attention to the context } \\
\text { in which the symptoms are occurring and its possibility } \\
\text { of clinical practice. It has demonstrated applicability } \\
\text { in studies involving children with cancer, but further } \\
\text { research is needed to investigate and clarify the role of } \\
\text { indirect reporting of children's symptoms by parents or } \\
\text { other caregivers and health professionals. }\end{array}$ \\
\hline $\begin{array}{l}\text { Investigación que prueba } \\
\text { teoría: una aproximación desde } \\
\text { enfermería cardiovascular }{ }^{(10)} \\
\text { Colombia } \\
2012 \\
\text { Aquichan } \\
\text { SCiELO/CAPES JOURNALS } \\
\text { PORTAL* }\end{array}$ & $\begin{array}{l}\text { Verify the assumptions } \\
\text { of the first dimension of } \\
\text { the Conceptual Model of } \\
\text { Symptom Management. }\end{array}$ & $\begin{array}{l}\text { Type of study: methodological } \\
\text { research } \\
\text { Population/sample: } 380 \\
\text { women hospitalized with } \\
\text { confirmed diagnosis of acute } \\
\text { coronary syndrome }\end{array}$ & $\begin{array}{l}\text { Three observable components of the conceptual model } \\
\text { of symptom management were confirmed: perception, } \\
\text { evaluation and response. The presence of the non- } \\
\text { observable variable "symptom experience", which is } \\
\text { directly influenced by the observable component } \\
\text { "Assessment", was confirmed. }\end{array}$ \\
\hline $\begin{array}{l}\text { Disability Intervention Model for } \\
\text { Older Adults with Arthritis: An } \\
\text { Integration of Theory of Symptom } \\
\text { Management and Disablement } \\
\text { Process Model(11) } \\
\text { South Korea } \\
2014 \\
\text { Asian Nursing Research } \\
\text { PubMed* }\end{array}$ & $\begin{array}{l}\text { To present and carry out } \\
\text { critical reflection of two } \\
\text { models such as } \\
\text { a conceptual basis for } \\
\text { building the Disability } \\
\text { Intervention Model for } \\
\text { Older Adults with Arthritis. }\end{array}$ & $\begin{array}{l}\text { Type of study: review article } \\
\text { Population/sample: elderly } \\
\text { with arthritis }\end{array}$ & $\begin{array}{l}\text { The Disability Intervention Model for Older Adults with } \\
\text { Arthritis was developed based on two theories, one } \\
\text { being the Symptom Management Theory including } \\
\text { the three components of the theory: experience, } \\
\text { management strategies and symptom outcomes. It also } \\
\text { considered the domains "person","'environment","'health } \\
\text { and disease" in the relationships between the factors that } \\
\text { influence the care of elderly patients with rheumatoid } \\
\text { arthritis, understanding the impact of disease on } \\
\text { physical, cognitive, emotional and socioeconomic health. } \\
\text { Therefore, it can be used as a theoretical model aimed } \\
\text { at care and research to improve the functional status of } \\
\text { elderly patients with rheumatoid arthritis. }\end{array}$ \\
\hline $\begin{array}{l}\text { Respuestas de la mujer frente a los } \\
\text { síntomas de Síndrome Coronario } \\
\text { Agudo basados en el Modelo } \\
\text { Conceptual del Manejo de los } \\
\text { Síntomas } \\
\text { Colombia } \\
2014 \\
\text { Avances em enfermeira } \\
\text { PubMed* }\end{array}$ & $\begin{array}{l}\text { Describe the response } \\
\text { actions of the woman and } \\
\text { the time it takes to seek } \\
\text { help with the symptoms } \\
\text { that arise with Acute } \\
\text { Coronary Syndrome. }\end{array}$ & $\begin{array}{l}\text { Type of study: quantitative- } \\
\text { descriptive cross-section } \\
\text { Population/sample: } 80 \text { women } \\
\text { hospitalized with diagnosis of } \\
\text { acute coronary syndrome }\end{array}$ & $\begin{array}{l}\text { This study promoted the understanding of the } \\
\text { phenomenon of response of women to the symptoms } \\
\text { of Acute Coronary Syndrome and pointed out the } \\
\text { contribution of the conceptual model of symptom } \\
\text { management associated with the identification of the } \\
\text { various responses of women and how they contribute } \\
\text { to the understanding of the time delay in seeking care } \\
\text { and the actions and factors that influence the severity } \\
\text { of the syndrome. }\end{array}$ \\
\hline $\begin{array}{l}\text { Perioperative site: an analysis } \\
\text { from the perspective of the } \\
\text { Symptom Management } \\
\text { Theory } \\
\text { Brazil } \\
2015\end{array}$ & $\begin{array}{l}\text { To analyze, within the } \\
\text { perspective of the } \\
\text { Symptom Management } \\
\text { Theory, what exists in } \\
\text { the literature about the } \\
\text { symptom "perioperative } \\
\text { headquarters" plus the } \\
\text { experience of the Study } \\
\text { and Research Group of the } \\
\text { Perioperative Headquarters. }\end{array}$ & $\begin{array}{l}\text { Type of study: theoretical } \\
\text { reflection } \\
\text { Population/sample: none }\end{array}$ & $\begin{array}{l}\text { The symptom of the perioperative site analyzed from } \\
\text { the perspective of the Symptom Management Theory } \\
\text { was considered in its multifactorial aspects, highlighting } \\
\text { the interrelation of the domains"person","environment", } \\
\text { "health state/disease" and in the dimensions "symptom } \\
\text { experience","symptom management strategies" } \\
\text { and "symptom repercussions", with the purpose } \\
\text { of highlighting it. It was observed that it has been } \\
\text { insufficiently valued, registered and treated in clinical } \\
\text { practice. }\end{array}$ \\
\hline
\end{tabular}




\begin{tabular}{|c|c|c|c|}
\hline $\begin{array}{l}\text { Title, country, year of } \\
\text { publication, journal and } \\
\text { virtual library/information } \\
\text { source }\end{array}$ & Objective & $\begin{array}{l}\text { Method (Type of study, } \\
\text { Participants) }\end{array}$ & Main results \\
\hline $\begin{array}{l}\text { I'm thirsty! Experience of } \\
\text { the surgical patient in the } \\
\text { perioperative period }{ }^{(14)} \\
\text { Brazil } \\
2016 \\
\text { Journal of the Brazilian } \\
\text { Association of Surgical Center } \\
\text { Nurses, Anesthesia Recovery } \\
\text { and Sterilization Material Center } \\
\text { VHL }^{*}\end{array}$ & $\begin{array}{l}\text { To reveal the experience of } \\
\text { the surgical patient in the } \\
\text { immediate postoperative } \\
\text { period in relation to } \\
\text { the headquarters, in } \\
\text { the perspective of the } \\
\text { Symptom Management } \\
\text { Theory. }\end{array}$ & $\begin{array}{l}\text { Type of study: qualitative } \\
\text { Population/sample: } 14 \\
\text { postoperative patients } \\
\text { (orthopedic, gynecological, } \\
\text { neurological and digestive } \\
\text { tract surgery) admitted to the } \\
\text { infirmary }\end{array}$ & $\begin{array}{l}\text { From the perspective of the Symptom Management } \\
\text { Theory, the thirst for the multivariousness of the } \\
\text { symptom is perceived and experienced through } \\
\text { physical repercussions such as dry mouth, dry and } \\
\text { cracked lips, salivary alteration and in the texture of the } \\
\text { tongue and sensation of suffocation and weakness; } \\
\text { the emotional repercussions reflect feelings such as } \\
\text { anguish, fear and impotence before the symptom. }\end{array}$ \\
\hline $\begin{array}{l}\text { Symptom management in } \\
\text { Behcet's disease }^{(15)} \\
\text { Turkey } \\
2018 \\
\text { Journal of Pakistan Medical } \\
\text { Association } \\
\text { PubMed* }\end{array}$ & $\begin{array}{l}\text { Identify the symptoms } \\
\text { experienced by patients } \\
\text { diagnosed with Behcet's } \\
\text { disease and how patients } \\
\text { deal with them. }\end{array}$ & $\begin{array}{l}\text { Type of study: qualitative } \\
\text { Population/sample: } 35 \\
\text { patients with Behcet's disease }\end{array}$ & $\begin{array}{l}\text { The Unpleasant Symptoms Theory and the Symptom } \\
\text { Management Theory were used to identify patients' } \\
\text { symptoms and coping methods. The symptoms reported } \\
\text { by the participants were: lesions in the oral and genital } \\
\text { mucosa, blurred vision, intense pain, neurological and } \\
\text { joint involvement, boredom, depression, stress and } \\
\text { fear. The symptoms reported were perceived by the } \\
\text { participants as negative, and it was concluded that they } \\
\text { affected their lives and needed effective management. }\end{array}$ \\
\hline $\begin{array}{l}\text { Bowel symptoms and self-care } \\
\text { strategies of survivors in the } \\
\text { process of restoration after } \\
\text { low anterior resection of rectal } \\
\text { cancer }{ }^{(16)} \\
\text { China } \\
2018 \\
\text { Biomedical Central Surgery } \\
\text { PubMed* }\end{array}$ & $\begin{array}{l}\text { Identify intestinal } \\
\text { symptoms and self-care } \\
\text { strategies for rectal cancer } \\
\text { survivors during the } \\
\text { recovery process after } \\
\text { resection surgery. }\end{array}$ & $\begin{array}{l}\text { Type of study: qualitative } \\
\text { Population/sample: } 100 \text { adult } \\
\text { patients }\end{array}$ & $\begin{array}{l}\text { The participants'intestinal symptoms and post-surgery } \\
\text { self-care strategies were investigated through a } \\
\text { structured interview tool based on the dimensions of } \\
\text { the “Symptom Management Theory", including the } \\
\text { experiences and symptom management strategies. } \\
\text { Among the results, it was observed that more than } 90 \% \\
\text { of the patients presented changes in intestinal habits } \\
\text { (perianal and abdominal pain, excessive flates, perianal } \\
\text { itching, fecal incontinence, decreased sensitivity and } \\
\text { perception of elimination, incomplete fecal elimination } \\
\text { and dirt) and the self-care strategies adopted by the } \\
\text { participants included diet, medications for the intestine, } \\
\text { management of practices and exercises. }\end{array}$ \\
\hline $\begin{array}{l}\text { Exploring our understanding } \\
\text { of fatigue among adolescents } \\
\text { living with HIV*: Highlighting the } \\
\text { unknown } \\
\text { United Kingdom } \\
2019 \\
\text { Journal of Health Psychology } \\
\text { PubMed* }\end{array}$ & $\begin{array}{l}\text { Apply the symptom } \\
\text { management model to } \\
\text { conceptualize fatigue } \\
\text { among adolescents with } \\
\text { HIV*. }\end{array}$ & $\begin{array}{l}\text { Type of study: critical reflection } \\
\text { Population/sample: } \\
\text { adolescents with HIV* }\end{array}$ & $\begin{array}{l}\text { The symptom management model can be a useful } \\
\text { theoretical framework for linking research results to } \\
\text { symptom and outcome management. Correcting } \\
\text { individual fatigue through self-management strategies, } \\
\text { particularly in early adolescence, can improve outcomes } \\
\text { by increasing quality of life, decreasing school } \\
\text { absenteeism and low achievement, and improving } \\
\text { future prospects of adolescents with HIV. }\end{array}$ \\
\hline
\end{tabular}

Coordination for the Improvement of Higher Level Personnel; VHL - Virtual Health Library; HIV - Human Immunodeficiency Virus.

Chart 3 - Approach to the domains, components of the Symptom Management Theory and strategies reported by the participants or suggested by the authors for the management of symptoms presented in the selected studies

\begin{tabular}{|c|c|c|c|c|}
\hline Study & $\begin{array}{l}\text { Clinical diagnosis and } \\
\text { symptom or group of } \\
\text { symptoms }\end{array}$ & $\begin{array}{l}\text { Domains } \\
\text { addressed }\end{array}$ & $\begin{array}{l}\text { Components } \\
\text { addressed }\end{array}$ & $\begin{array}{l}\text { Strategies reported by participants or } \\
\text { suggested by authors for symptom } \\
\text { management }\end{array}$ \\
\hline $\begin{array}{l}\text { Conceptual Model of } \\
\text { Symptom-Focused Diabetes } \\
\text { Care for African Americans }{ }^{(9)}\end{array}$ & $\begin{array}{l}\text { Diabetes mellitus: } \\
\text { - Symptoms of } \\
\text { hyperglycemia; } \\
\text { - Symptoms of hypoglycemia; } \\
\text { - Numbness, tingling or pain } \\
\text { in the feet. }\end{array}$ & $\begin{array}{l}\text { - Person; } \\
\text { - Environment; } \\
\text { - Health and } \\
\text { disease. }\end{array}$ & $\begin{array}{l}\text { - Experience of } \\
\text { symptoms; } \\
\text { - Strategies of symptom } \\
\text { management; } \\
\text { - Results of symptoms. }\end{array}$ & $\begin{array}{l}\text { Strategies suggested by the authors: } \\
\text { - Health education practices; } \\
\text { - Active listening and welcome; } \\
\text { - Physiological (clinical management); } \\
\text { - Behavioral (self-care practices); } \\
\text { - Socio-psychological (confrontation, stress, } \\
\text { community resources). }\end{array}$ \\
\hline $\begin{array}{l}\text { Analysis of the UCSF } \\
\text { Symptom Management } \\
\text { Theory: Implications for } \\
\text { Pediatric Oncology Nursing }\end{array}$ & $\begin{array}{l}\text { Child and youth cancer: } \\
\text { - General symptoms of } \\
\text { oncopediatric patients. }\end{array}$ & $\begin{array}{l}\text { - Person; } \\
\text { - Environment; } \\
\text { - Health and } \\
\text { disease. }\end{array}$ & $\begin{array}{l}\text { - Experience of } \\
\text { symptoms; } \\
\text { - Strategies of symptom } \\
\text { management; } \\
\text { - Results of symptoms. }\end{array}$ & Did not present. \\
\hline
\end{tabular}




\begin{tabular}{|c|c|c|c|c|}
\hline Study & $\begin{array}{l}\text { Clinical diagnosis and } \\
\text { symptom or group of } \\
\text { symptoms }\end{array}$ & $\begin{array}{l}\text { Domains } \\
\text { addressed }\end{array}$ & $\begin{array}{l}\text { Components } \\
\text { addressed }\end{array}$ & $\begin{array}{l}\text { Strategies reported by participants or } \\
\text { suggested by authors for symptom } \\
\text { management }\end{array}$ \\
\hline $\begin{array}{l}\text { Investigación que prueba } \\
\text { teoría: una aproximación } \\
\text { desde enfermería } \\
\text { cardiovascular }^{(10)}\end{array}$ & $\begin{array}{l}\text { Acute coronary syndrome: } \\
\text { - Did not present. }\end{array}$ & $\begin{array}{l}\text { - Person; } \\
\text { - Environment; } \\
\text { - Health and } \\
\text { disease. }\end{array}$ & $\begin{array}{l}\text { - Experience of } \\
\text { symptoms. }\end{array}$ & Did not present. \\
\hline $\begin{array}{l}\text { Disability Intervention Model } \\
\text { for Older Adults with Arthritis: } \\
\text { An Integration of Theory } \\
\text { of Symptom Management } \\
\text { and Disablement Process } \\
\text { Model }^{(11)}\end{array}$ & $\begin{array}{l}\text { Rheumatoid arthritis: } \\
\text { - Pain; } \\
\text { - Rigidity and edema in the } \\
\text { joints; } \\
\text { - Fatigue. }\end{array}$ & $\begin{array}{l}\text { - Person; } \\
\text { - Environment; } \\
\text { - Health and } \\
\text { disease. }\end{array}$ & $\begin{array}{l}\text { - Experience of } \\
\text { symptoms; } \\
\text { - Strategies of symptom } \\
\text { management; } \\
\text { - Results of symptoms. }\end{array}$ & $\begin{array}{l}\text { Strategies suggested by the authors: } \\
\text { - Administer drugs; } \\
\text { - Stimulating self-care practices and facing the } \\
\text { disease. }\end{array}$ \\
\hline $\begin{array}{l}\text { Respuestas de la mujer } \\
\text { frente a los síntomas de } \\
\text { Síndrome Coronario Agudo } \\
\text { basados en el Modelo } \\
\text { Conceptual del Manejo de } \\
\text { los Síntomas }\end{array}$ & $\begin{array}{l}\text { Acute coronary syndrome: } \\
\text { - Did not present. }\end{array}$ & $\begin{array}{l}\text { - Person; } \\
\text { - Environment; } \\
\text { - Health and } \\
\text { disease. }\end{array}$ & $\begin{array}{l}\text { - Experience of } \\
\text { symptoms; } \\
\text { - Strategies of symptom } \\
\text { management; } \\
\text { - Results of symptoms. }\end{array}$ & $\begin{array}{l}\text { Strategies reported by participants: } \\
\text { - Use of home medicines; } \\
\text { - Oral hydration; } \\
\text { - Control of respiratory pattern; } \\
\text { - Waiting for the symptoms to pass; } \\
\text { - Calling the ambulance. } \\
\text { Strategies suggested by the authors: } \\
\text { - Develop interventions for the care of women } \\
\text { with acute coronary syndrome; } \\
\text { - To evaluate interventions and impact on } \\
\text { responses of women with acute coronary } \\
\text { syndrome; } \\
\text { - Implement effective screening systems } \\
\text { in emergency services that allow nursing } \\
\text { professionals to quickly identify the event and } \\
\text { initiate care; } \\
\text { - Develop surveys to evaluate responses to } \\
\text { symptoms of acute coronary syndrome. }\end{array}$ \\
\hline $\begin{array}{l}\text { Perioperative site: } \\
\text { an analysis from the } \\
\text { perspective of the } \\
\text { Symptom Management } \\
\text { Theory }^{(13)}\end{array}$ & $\begin{array}{l}\text { Patient in immediate } \\
\text { postoperative period: } \\
\text { - Perioperative site. }\end{array}$ & $\begin{array}{l}\text { - Person; } \\
\text { - Environment; } \\
\text { - Health and } \\
\text { disease. }\end{array}$ & $\begin{array}{l}\text { - Experience of } \\
\text { symptoms; } \\
\text { - Strategies of symptom } \\
\text { management; } \\
\text { - Results of symptoms. }\end{array}$ & $\begin{array}{l}\text { Strategies suggested by the authors: } \\
\text { - Offer ice and menthol; } \\
\text { - Stimulate gargle with cold water; } \\
\text { - Apply moist gauze with water or saline } \\
\text { solution on oral mucosa; } \\
\text { - Offer water and ice up to } 50 \mathrm{ml} \text { (limit the } \\
\text { volume of liquid to be safely administered and } \\
\text { reduce the risk of bronchoaspiration). }\end{array}$ \\
\hline $\begin{array}{l}\text { I'm thirsty! Experience of } \\
\text { the surgical patient in the } \\
\text { perioperative period }^{(14)}\end{array}$ & $\begin{array}{l}\text { Patient in immediate } \\
\text { postoperative period: } \\
\text { - Perioperative site. }\end{array}$ & $\begin{array}{l}\text { - Person; } \\
\text { - Environment; } \\
\text { - Health and } \\
\text { disease. }\end{array}$ & $\begin{array}{l}\text { - Experience of } \\
\text { symptoms; } \\
\text { - Strategies of symptom } \\
\text { management; } \\
\text { - Results of symptoms. }\end{array}$ & $\begin{array}{l}\text { Strategies reported by participants: } \\
\text { - Offer ice popsicle; } \\
\text { - Moisten oral mucosa with cotton soaked in } \\
\text { water at room temperature. }\end{array}$ \\
\hline $\begin{array}{l}\text { Symptom management in } \\
\text { Behcet's disease }^{(15)}\end{array}$ & $\begin{array}{l}\text { Behcet's disease: } \\
\text { - Lesions in the oral mucosa } \\
\text { and genitals; } \\
\text { - Blurred vision; } \\
\text { - Intense pain; } \\
\text { - Neurological and joint } \\
\text { impairment; } \\
\text { - Boredom; } \\
\text { - Depression and stress; } \\
\text { - Fear. }\end{array}$ & $\begin{array}{l}\text { - Pessoa; } \\
\text { - Ambiente; } \\
\text { - Saúde e } \\
\text { doença. }\end{array}$ & $\begin{array}{l}\text { - Experience of } \\
\text { symptoms; } \\
\text { - Strategies of symptom } \\
\text { management; } \\
\text { - Results of symptoms. }\end{array}$ & $\begin{array}{l}\text { Strategies suggested by the authors: } \\
\text { - Use of analgesic drugs; } \\
\text { - Complementary therapies; } \\
\text { - Stimulation to positive thoughts and facing } \\
\text { the disease. }\end{array}$ \\
\hline $\begin{array}{l}\text { Bowel symptoms and self- } \\
\text { care strategies of survivors } \\
\text { in the process of restoration } \\
\text { after low anterior resection } \\
\text { of rectal cancer }^{(16)}\end{array}$ & $\begin{array}{l}\text { Patient in the postoperative } \\
\text { period of colorectal surgery: } \\
\text { - Perianal and abdominal pain; } \\
\text { - excessive flatos; } \\
\text { - Perianal itching; } \\
\text { - Fecal incontinence; } \\
\text { - Decreased sensitivity and } \\
\text { perception of eliminations; } \\
\text { - Incomplete fecal elimination; } \\
\text { - Dirt. }\end{array}$ & $\begin{array}{l}\text { - Person; } \\
\text { - Environment; } \\
\text { - Health and } \\
\text { disease. }\end{array}$ & $\begin{array}{l}\text { - Experience of } \\
\text { symptoms; } \\
\text { - Strategies of symptom } \\
\text { management; } \\
\text { - Results of symptoms. }\end{array}$ & $\begin{array}{l}\text { Strategies reported by participants: } \\
\text { - Use of medication; } \\
\text { - Dietary intake with fiber and low fat content; } \\
\text { - Seat bath with water and saline solution in } \\
\text { cases of perianal pain. }\end{array}$ \\
\hline $\begin{array}{l}\text { Exploring our understanding } \\
\text { of fatigue among } \\
\text { adolescents living with HIV*: } \\
\text { Highlighting the unknown }{ }^{(17)}\end{array}$ & $\begin{array}{l}\text { Human Immunodeficiency } \\
\text { Virus: } \\
\text { - Fatigue }\end{array}$ & $\begin{array}{l}\text { - Person; } \\
\text { - Environment; } \\
\text { - Health and } \\
\text { disease. }\end{array}$ & $\begin{array}{l}\text { - Experience of } \\
\text { symptoms; } \\
\text { - Strategies of symptom } \\
\text { management; } \\
\text { - Results of symptoms. }\end{array}$ & $\begin{array}{l}\text { Strategies suggested by the authors: } \\
\text { - Planning cognitive behavioral interventions; } \\
\text { - Stimulate physical activities; } \\
\text { - Plan actions to improve sleep pattern, mood } \\
\text { and reduce anxiety. }\end{array}$ \\
\hline
\end{tabular}




\section{DISCUSSION}

The ten studies selected, of which six ${ }^{(9-10,12,14-16)}$ presented pri-

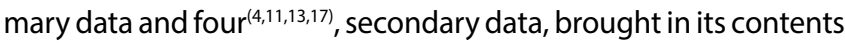
the use and application of the Symptom Management Theory or the Symptom Management Model in various populations, which included children, adolescents, adults and elderly and presented its applicability in nursing care.

The Symptom Management Theory or Model was considered applicable because its theoretical assumptions allow its use to all individuals who experience the symptom or are susceptible to develop it, besides allowing the manifestation of the caregivers in relation to the symptoms experienced by their relatives or patients as presented in the selected studies.

It was observed that, independently of the clinical conditions of the participants, whether in chronic or acute situations, the theory was applied; however, facing the premise that the management of symptoms is a dynamic process, which can suffer modifications in its results according to the direction of the interrelations between its domains and components, it was sought to explore, in the studies that compose this review of scope, the indications that represented the applicability of the theory in nursing researches.

Thus, regarding the first domain "person", personal, demographic, sociological, psychological, physiological and developmental variables that are intrinsic to the way the individual perceives and responds to the experience of the symptom must be considered, but they can be more or less manifested depending on the symptom or group of symptoms and the population that manifests it ${ }^{(3)}$.

From this perspective, the examples mentioned in two studies that presented the symptom "thirst in patients in the immediate postoperative period", perceived by them intensely and as an extremely unpleasant symptom, for many health professionals is an undervalued, under-measured, under-treated symptom and without protocols for clinical practice. For these patients, thirst may be accentuated by other variables besides the physiological, such as stress and anxiety, which increase thirst, and anxiety, which increases because of thirst, forming a vicious cycle to be interrupted through strategies to control the symptom ${ }^{(13-14)}$.

A study to evaluate fatigue in adolescents with HIV highlighted that this population has its particularities due to development in the life cycle and usually has less emotional awareness than adults, which can affect the experience of symptoms such as fatigue. For adolescents, fatigue may focus more on the physiological variable, with physical sensations and changes in daily activities, than on cognitive and emotional aspects. Furthermore, when related to demographic variables, the authors compare information that fatigue is greater in women and older patients, factors that should be considered because they influence the experience, management and outcome of symptoms ${ }^{(17)}$.

In relation to the "environment" domain, one must consider the context in which the symptom occurs and include the physical, social and cultural variables, which include the home, work environment, hospital, social support network, interpersonal relationships and the beliefs, values and practices of an ethnic group $^{(3)}$. This domain was highlighted in the study in which the participants were African-American women with type II diabetes mellitus and lived in a rural area of the Southeastern United States of America. The strategies for the management of the symptoms experienced were thought out including the context and reality in which they lived, emphasizing the practices of health education, welcome, orientation, stimulus to self-care actions and confrontation, considering the beliefs and cultural values, besides the clinical management to control the symptoms and disease ${ }^{(9)}$.

Another study highlighted the "environment" domain and pointed out variables related to cultural issues, bringing the culture as a justification for the time of demand for health services by women with acute coronary syndrome (ACS) after the onset of symptoms. Many times, women ignore what they are feeling, do not recognize the seriousness of the possible health problem and, because they assume their self-care, minimize their symptoms. In this case of risk of infarction, they delay the search for hospital treatment, thus increasing the morbidity and mortality of women with ACS and, consequently, influencing the strategies for managing the symptoms and their results ${ }^{(12)}$.

The third domain "health and disease" is composed of variables that include risk factors, diseases, injuries or disabilities and, like the other domains, may present direct and indirect effects on the experience, management and results of symptoms ${ }^{(3)}$. The risk factors can be hereditary or not, the health status is related to physiological functions and body structure, while the disease reflects the acute or chronic dysfunctions according to the pathology that affects the individual ${ }^{(10)}$. Regarding this domain, the selected studies mentioned the relation of these variables, correlating the symptomatology to the clinical conditions and the development of the disease of the populations approached. The articles involved: surgical procedures and emergency treatments ${ }^{(12-14,16)}$ in which strategies and care were pointed out to manage the acute symptoms triggered at that moment; as well as chronic conditions ${ }^{(4,9,11,15,17)}$, indicating, in addition to strategies for immediate care, care to be continuously developed to improve the quality of life of patients.

Thus, we observe that the domains "person", "environment", "health and disease" are interconnected concepts, and the amplitude of their manifestation will influence the relation of their variables and the components of SMT, such as: experience of symptoms, strategies of management of symptoms and results ${ }^{(18)}$.

The "symptom experience" component includes individual experience with the variables "perception of a symptom","evaluation of meaning" and "response to the symptom"(13,18). The perception of symptoms occurs when the individual perceives a change in the way he feels or behaves and, when evaluating his symptoms, makes judgments about the gravity, cause and effect in his life, and the responses consider the physiological, psychological, sociocultural and behavioral factors ${ }^{(3)}$.

Symptom management strategies" aim at mitigating, delaying or preventing a negative result, based on the evaluation of the individual experience, followed by the identification of an intervention strategy to be directed at one or more symptoms manifested by the patient ${ }^{(3,13)}$. The "symptom outcomes" that emerge from symptom management strategies and experiences should include the specifications of what (nature of the strategy), when, where, why, how much, for whom, and how, as interventions are planned and prescribed ${ }^{(3,18)}$. 
As presented in Table 3, nine studies ${ }^{(4,9,11-17)}$ approached in its content the three components of the theory presenting the particularities about the perception of the symptom, based on the experiences of the participants, such as the perioperative seat, with significant negative evaluation; pain reported by rheumatic patients; configuration of fatigue in seropositive adolescents; and difficulties in facing the diseases - making us reflect and corroborate the theoretical assumptions of SMT.

The individual, who experiences the symptom, evaluates it. This evaluation involves a set of factors that characterize the symptom experience (intensity, location, nature, frequency and affective impact) ${ }^{(3)}$, based on self-reporting, enabling the actual manifestation of the symptom experience for decision making regarding management strategies.

In this context, it is worth mentioning that SMT considers the evaluation of the symptoms by a caregiver of the one who experienced the symptom, being a considered challenge in a study on the applicability of the theory in the care of children with cancer ${ }^{(4)}$. The authors observe that parents and children can attribute different meanings to the symptoms perceived in pediatric cancer, a difference that may lead to difficulties in planning interventions ${ }^{(4)}$.

The evaluation of symptoms will depend on persistence, the need for continuous intervention and response to treatment. When a symptom is treated but persists, continuous intervention is necessary to control the recurrence or minimize its effect, as well as monitoring the results for changes or not in the strategies of care $^{(3)}$. Examples of ongoing strategies were cited by three studies $^{(9,12,17)}$.

As for the methodological study, it was the only one to approach the first component of SMT, "experience of the symptom", because with the objective of testing the concepts of this component, it proved its existence, emphasizing the variable "evaluation" and contributing to the theoretical content, research and practice of nursing ${ }^{(10)}$.

In relation to theoretical reflection studies $(4,11,13,17)$, it is worth mentioning that they were included to compose this review, since they analyzed the SMT correlating the contexts and themes of each of the publications; presenting the domains, the components of the theory; raising the limitations, challenges and contributions for nursing care.

\section{Study limitations}

This review presented limitations regarding the search strategy: only virtual libraries and free access information sources were used; and, selected studies were available for online consultation. In addition, although the studies pointed out examples of symptom management strategies, two did not mention them in their content, which could strengthen the knowledge related to nursing care planning.

\section{Contributions to Nursing}

The development of nursing theories, including medium range theories that seek less abstract and more specific concepts for the details of nursing practice, contributes to the development of a new theoretical and scientific knowledge ${ }^{(1)}$. The use of SMT, besides the scientific contributions and theoretical bases that support the investigations about the symptoms, collaborates for the instrumentation and understanding on the part of the nurses about the management of symptoms and assistance practice based on concepts and meta-paradigms, supporting the work and nursing care.

\section{CONCLUSIONS}

The selected studies highlighted the domains and components of SMT, the contexts and its applicability in nursing care. The content of the theory was applied considering the particularities concerning the characteristics of the population, the disease and the relationship between the SMT variables. It was verified that to understand the interaction of these elements is essential in the elaboration and planning of actions for the control of the symptoms in an effective way.

Although the results of this review point to the applicability of SMT, knowledge gaps related to the deficiency of primary studies that address all the elements and components of theory in a thorough and explicit manner were observed; and to studies that contemplate theoretical assumptions that the report of symptom manifestation by patients can be expressed by other people as family members, caregivers and health professionals - this is a challenge for researchers, since the studies focus on the patient, but it is necessary to investigate if the insertion of the caregiver, his or her location in the dimensions and his or her relationship in the SMT components can or cannot contribute to improve the symptoms management process.

Thus, it is expected that the gaps regarding this theme will be filled with studies dealing with the approach of nursing theories and their applicability; and also with reflections that may collaborate with the development of care practices in the care, managerial, teaching and research dimensions.

\section{REFERENCES}

1. Leandro TA, Nunes MM, Teixeira IX, Lopes MVO, Araújo TL, Lima FET, et al. Development of middle-range theories in Nursing. Rev Bras Enferm. 2020;73(1):e20170893. https://doi.org/10.1590/0034-7167-2017-0893

2. Bousso RS, Poles K, Cruz DALM. Conceitos e teorias na enfermagem. Rev Esc Enferm USP. 2014;48(1):144-8. https://doi.org/10.1590/ S0080-623420140000100018

3. Dodd M, Janson S, Facione N, Faucett J, Froelicher ES, Humphreys J, et al. Advancing the science of symptom management. J Adv Nurs. 2001;33(5):668-76. https://doi.org/10.1046/j.1365-2648.2001.01697.x 
4. Linder, L. Analysis of the UCSF Symptom Management Theory: implications for pediatric oncology nursing. J Pediatr Oncol Nurs. 2010;27(6):316-24. https://doi.org/10.1177/1043454210368532

5. Eicher M, Delmas P, Cohen C, Baeriswyl C, Viens Python N. Version Française de la Théorie de Gestion des Symptômes (TGS) et son application. Rech Soins Infirm. 2013;112:14-25. https://doi.org/10.3917/rsi.112.0014

6. Arksey H, O'Malley L. Scoping studies: towards a methodological framework. Int J Soc Res Methodol. 2005;8(1):19-32. https://doi. org/10.1080/1364557032000119616

7. Peters MDJ, Godfrey C, McInerney P, Munn Z, Tricco AC, Khalil, H. Chapter 11: Scoping Reviews (2020 version). In: Aromataris E, Munn Z (Eds). JBI Manual for Evidence Synthesis, JBI; 2020 [cited 2020 Jul 15]. Available from: https://synthesismanual.jbi.global

8. Tricco AC, Lillie E, Zarin W. PRISMA Extension for Scoping Reviews (PRISMA-ScR): checklist and explanation. Ann Intern Med. 2018;467-473. https://doi.org/10.7326/M18-0850

9. Skelly AH, Leeman J, Carlson J, Soward ACM, Burns D. Conceptual model of symptom-focused diabetes care for African Americans. J Nurs Scholarsh. 2008;40(3):261-7. https://doi.org/10.1111/j.1547-5069.2008.00236.x

10. Céspedes-Cuevas VM. Investigación que prueba teoría: una aproximación desde enfermería cardiovascular. Aquichan[Internet]. 2012 [cited 2020 Aug 12];2(12):97-108. Available from: https://aquichan.unisabana.edu.co/index.php/aquichan/article/view/1940/2923

11. Shin SY. Disability intervention model for older adults with arthritis: an integration of theory of symptom management and disablement process model. Asian Nurs Res. 2014;8:241-6. https://doi.org/10.1016/j.anr.2014.08.004

12. Garcia CIP, Montoya XS. Respuestas de la mujer frente a los síntomas de Síndrome Coronario Agudo basados en el Modelo Conceptual del Manejo de los Síntomas. Av Enferm. 2014;32(1):102-13. https://doi.org/10.15446/av.enferm.v32n1.46068

13. Conchon MF, Nascimento LA, Fonseca LF, Aroni P. Perioperative thirst: an analysis from the perspective of the Symptom Management Theory. Rev Esc Enferm USP. 2015;49(1):122-8. https://doi.org/10.1590/S0080-623420150000100016

14. Silva RCJL, Aroni P, Fonseca LF. I am thirsty! experience of the surgical patient in the perioperative period. Rev SOBECC. 2016;21(2):75-81. https://doi.org/10.5327/Z1414-4425201600020003

15. Özel F, Türeyen AE, Aykar FS. Symptom management in Behcet's disease. J Pak Med Assoc [Internet]. 2018[cited 2020 Aug 12];68(1):46-9. Available from: https://pubmed.ncbi.nlm.nih.gov/29371717/

16. Yin L, Fan L, Tan R, Yang G, Jiang F, Zhang C, et al. Bowel symptoms and self-care strategies of survivors in the process of restoration after low anterior resection of rectal cancer. BMC Surg. 2018;18(1):35. https://doi.org/10.1186/s12893-018-0368-5

17. Loades ME, Kagee A. Exploring our understanding of fatigue among adolescents living with HIV: highlighting the unknown. J Health Psychol. 2019;24(1):125-36. https://doi.org/10.1177/1359105317710320

18. Bernal-Cárdenas CY, Céspedes-Cuevas VM, Sanhueza-Alvarado OI. Modelo conceptual del manejo del síntoma: evaluación y crítica. Aquichan. 2018;18(3):311-26. https://doi.org/10.5294/aqui.2018.18.3.6 